\title{
Reframing Public Spaces: from Recreational Amenity to Civic Good in Resilient Cities. COVID-19 Offers an Opportunity to Re-evaluate Neighbourhood Spaces to Ensure they are Available to All
}

\author{
Kevin Fan Hsu \\ Centre for Liveable Cities, Singapore \\ kevin_hsu_from.TP@mnd.gov.sg
}

\begin{abstract}
Cities emerging from the pandemic increasingly recognize that public spaces are a critical element of resilience, not merely recreational amenities. Future public spaces must be designed to accommodate more diverse and distanced activities, and may even change function entirely during public health emergencies. The need for informal public spaces has also become apparent, and cities can benefit from identifying them as resources and integrating them into land-use plans. Parks, sidewalks and cycling paths can be justified as investments in resilience and survivability and quickly expanded. Their provision must be viewed through the lens of social and spatial equity: in many cities, not every person or community has convenient access to these critical public goods. Planners must go beyond metrics on the mere availability or density of public spaces, and delve deeper to assess the quality of spaces, and the ability of different demographic groups to reach them.

Historic neighbourhoods that developed organically offer useful inspiration when designing for equitable access and daily convenience, and can also accommodate the dispersal of jobs away from central business districts. Efforts to develop decentralised, "complete" neighbourhoods can be a boon for adaptive reuse, public space provision, and greater variety of work settings, while public areas of civic buildings can be re-imagined as nodes of collaboration in a knowledge-based economy. Beyond building infrastructure, maintaining lively and welcoming public spaces requires empathy, respect for the commons, and care for fellow human beings. Physical spaces in a city can only be fully and genuinely "public" if they are safe, and open to everyone, regardless of age, language, identity, sexual orientation or ability. As cities undertake revitalization efforts following the pandemic, they must strive to ensure such places are available to all.
\end{abstract}

Keywords: resilience, urban planning, equity, public space, post-pandemic design

To cite this article:

Hsu, K. F. (2020). Reframing Public Spaces: from Recreational Amenity to Civic Good in Resilient Cities. COVID-19 Offers an Opportunity to Re-evaluate Neighbourhood Spaces to Ensure they are Available to All, The Journal of Public Space, 5(3), 67-82, DOI I0.3289I/jps.v5i3.1416

This article has been double blind peer reviewed and accepted for publication in The Journal of Public Space.

(C) This work is licensed under a Creative Commons Attribution - Non Commercial 4.0 International License https://creativecommons.org/licenses/by-nc/4.0/ 
With repeated lockdowns forcing the populace to sequester indoors, the global COVID-I9 pandemic has provoked a host of questions about public space. Around the world, governments are re-examining land use policies, as they contend with the social challenges and disparities revealed — and amplified - by orders to stay home for extended periods.' As cities emerge from the pandemic to explore a "new normal," they will inevitably adjust their visions of the urban future. This article offers observations on the value, planning and function of public spaces during and after the pandemic, drawing inspiration from several international examples, including the densely settled city-state of Singapore.

\section{"Public space" is a critical element of resilience, rather than an optional recreational amenity}

Planners have long extolled the salubrious effects of light, air, and open space, specified in zoning ordinances and planning norms. Early thinking around parks considered them recreational spaces (Bassett, 1938; Mason, 2006), offering benefits such as leisure, commemorative value, and areas for games and sports (Taylor, 2009). As cities, particularly in North America and Europe, developed more sophisticated understandings of parks and public spaces, a much wider array of values were ascribed to them, including social, economic and environmental goods, civic identity, and the promotion of physical health and mental well-being (Design Council UK, 2003; Peiser and Shwann, 1993; Maas et al., 2009; Henderson, 2012; Sturm and Cohen, 2014; Larson et. Al, 2016; Lennon et al., 2017).

In Singapore, efforts to develop parks and enhance greenery after independence in 1965 were intended to raise "the morale of the people and [give] them pride in their surroundings," (Lee, 2000) and act as a "social leveller" across different socio-economic groups (Er, 20l8). A pioneering generation of leaders combined urban density with greenery to give rise to today's liveable context. From the early idea of a "Garden City," (National Library Board, 2020) to more recent calls to grow into a "City in Nature," (Khoo, 2017; National Parks Board, 2020) the island city-state has consistently set aside land, planted trees and shrubs, and explored new ways to introduce vertical and rooftop greenery into the urban landscape (Rowe and Lee, 2019; Centre for Liveable Cities and National Park Board, 2015). The Singapore Botanical Gardens, which supplied expertise and materiel for greening initiatives during the 1970s, was even inscribed on the UNESCO World Heritage list in 2015 (UNESCO, 20I5).

However, there are still cities in many parts of the world today where a significant portion of the population does not have access to parks and open spaces. The COVID19 pandemic heightens the urgency of ensuring such basic amenities are available to all. With people tethered to their homes for weeks or months, access to recreational space close by is more important than ever. Parks with sufficient area to permit movement and exercise are a public good with implications for system-level health. As cities strive to become resilient, they must look beyond disaster response and protections against sea-level rise, to recognize that public space provision is an essential good. Resilience indices can be updated to reflect households' access to public space, 
given stressors such as global pandemic. Safe public spaces in cities are not merely a factor that boosts liveability, but a critical feature that ensures survivability.

\section{Public spaces are not only for socialising; they are also places of transit, distance, and solitude}

The mental image of the social urban park is likely to transform, as plazas, central greens, and public squares evolve from focal points for mass gatherings, demonstrations, and inter-personal exchange, into places for separation and dispersal Johnson, 2002; Lee, 2009; Parkinson, 2012; Gul et al., 20I4; Hammond, 2019; Kwok and Chan, 2020). Humans are social creatures, so William Whyte's seminal observation about New York's public spaces -"what attracts people most, it would appear, is other people" (Whyte, 1980) -remains valid. At the same time, parks will have to serve multiple functions - not only as places for people to "mix, relax and meet in the city,"(Low et al., 2005) but also as places that can accommodate diverse, safely-distanced activities. In more extreme cases, parks may even be converted to temporary field hospitals, quarantine centres, or dormitories during a health emergency.

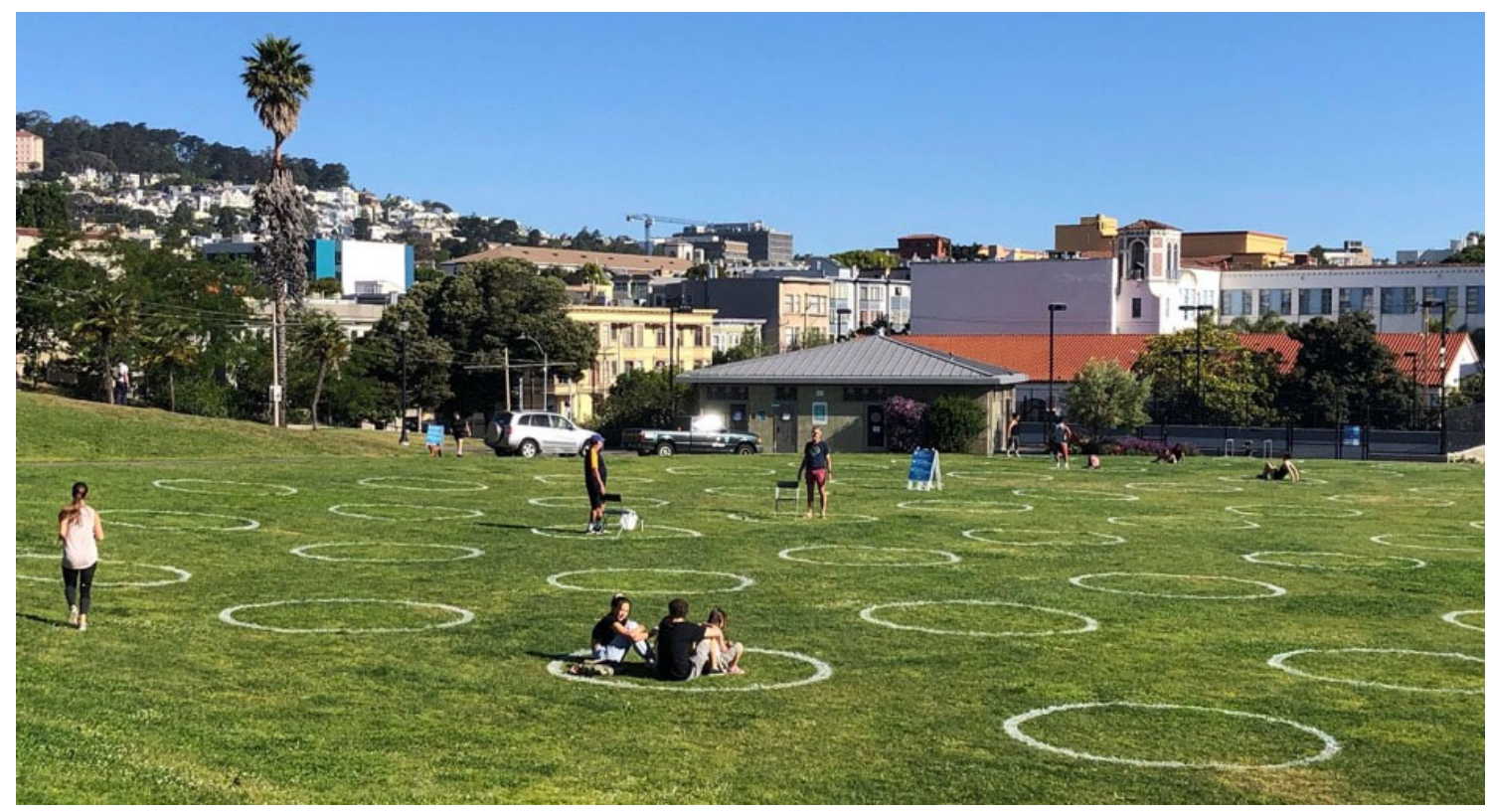

Figure I. "Human parking spaces” in Mission Dolores Park in San Francisco, May 2020. Photo by Natasha Chu.

Future architects and urban planners will wrestle with balancing the role of parks as places for physical distancing vs. sites of community-building that strengthen social bonds (Peters et al., 2009). Discussion of the dichotomous nature of parks-passive or active, regulated or unregulated, competitive or non-competitive-may well resurface (Harnik, 20I2). When seeking planning inspiration, designers can draw from other cultural traditions that view public space as spiritual retreat, source of solitude, or refuge (Thralls, 2018; Hammitt, 2002; Beatley, 2017; Goto, 2003). 
The value of informal spaces becomes apparent when these spaces disappear With the partial shutdown of many businesses, a city's informal gathering places-sites not necessarily marked as parks on a land-use document (Rupprecht and Byrne, 2014; Lutzoni, 2016) — have also been deeply impacted. In Singapore, for example, residents frequently gather in the local coffee shop or kopitiam, in hawker centres that serve meals, and in ground-floor "void decks" of public housing flats. Due to the pandemic, many of these places were closed, eliminating their normal civic function (Butler, 2016). Singapore has also designated a network of green corridors, utilising land alongside drainage canals and road reserves to link parks, nature areas, and other open spaces. This Park Connector Network (PCN) allows people to exercise, cycle and commute. While some informal social spaces were closed, the $\mathrm{PCN}$ remained open and consequently witnessed greater numbers of users than before.

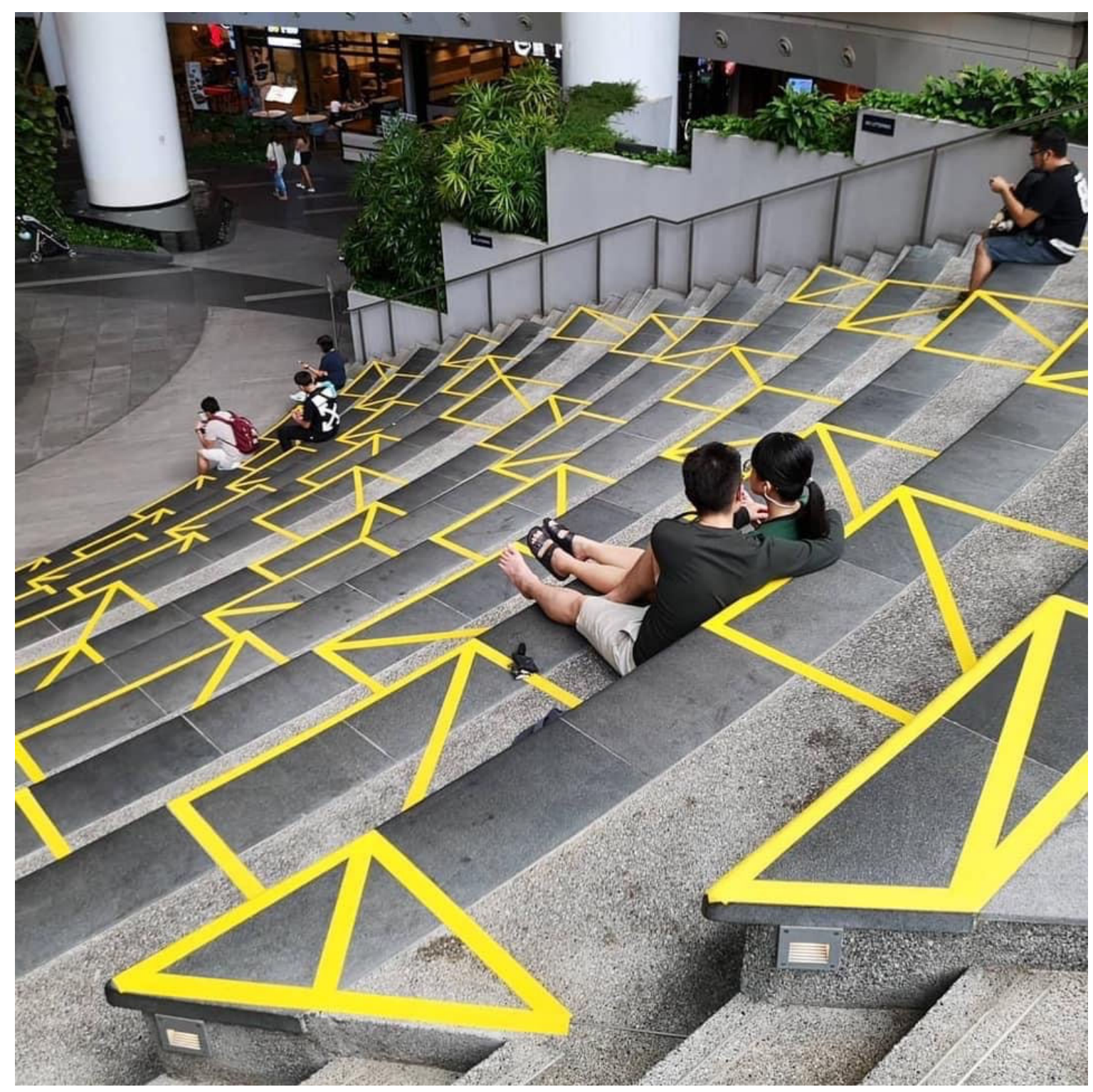

Figure 2. Seating has been carefully marked in public areas to promote safe distancing in Singapore. Photo by Emeric Lau. 


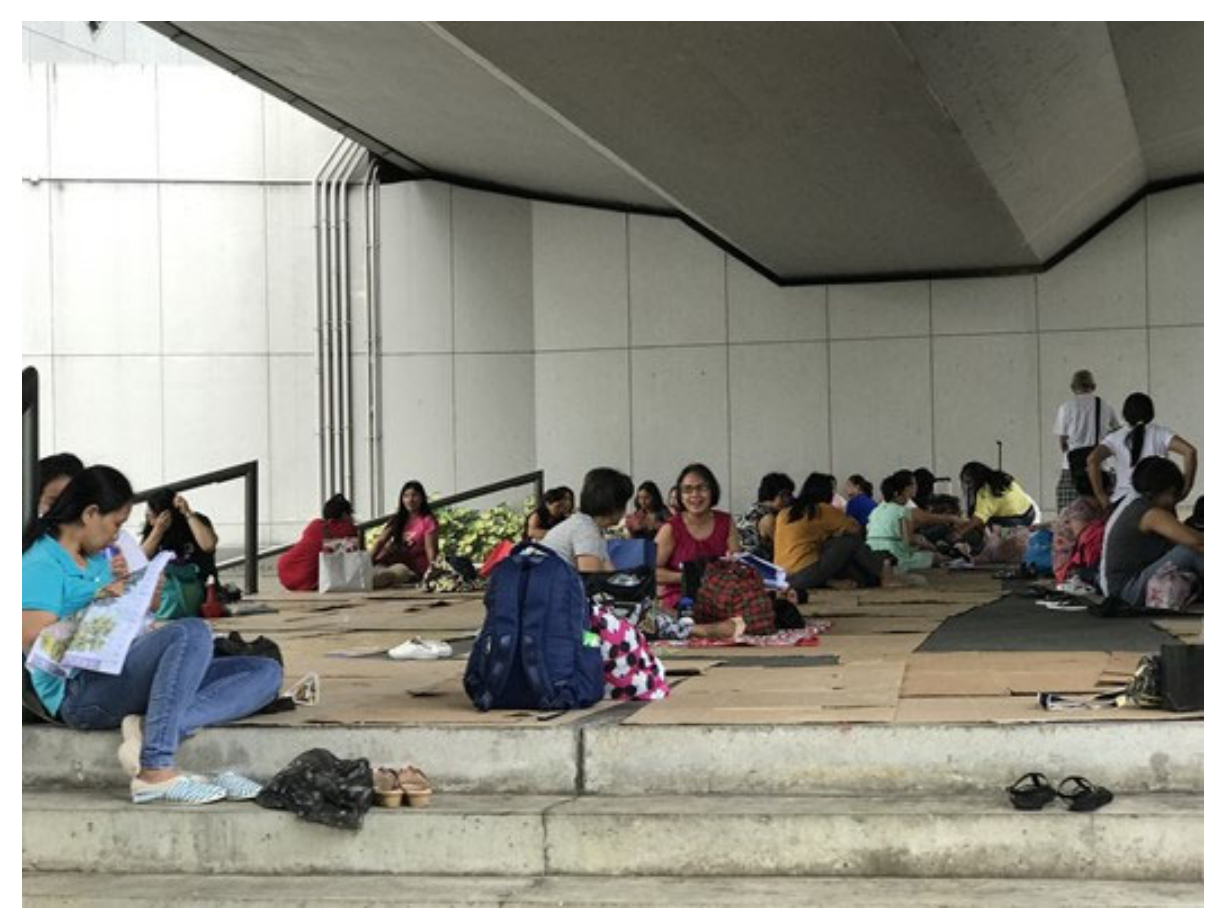

Figure 3. Unofficial public spaces accommodate many activities,

such as pre-pandemic weekend social gatherings in Hong Kong. Photo by Kevin Hsu.

As cities look to the future, planners can strive to identify informal spaces, inventory them as municipal and national assets, and include them in the city's land use plans.

Observing and engaging with the public in the places where they spend their daily lives would allow planners to better understand citizens' values and preferences. As the old adage goes, "We measure what we care about." Land use planning benefits from placing informal public spaces into dialogue with typologies of parks, park connectors, and greenery. Traditional parks are still needed, but informal spaces bring social value to households that should not be underestimated (Teo, 1997).

Assessing, responding to, and incorporating public sentiment about public spaces can also be strengthened (Hee and Ooi, 2003; Hee, 20I7). The National Parks Board has begun more extensive citizen consultation for the design of upcoming park facilities (The Straits Times, 2020), and the non-profit organization Participate in Design incorporates walking tours, mobile stations for community input, and other engagement strategies in its work on public amenities with town councils. The incoming generation of Singapore's national leaders has suggested such efforts at co-creation are desirable (Prime Minister's Office, 2019). After the pandemic, government planners will have the opportunity to reacquaint themselves with the value of what Ray Oldenburg calls "third places," or "informal public gathering places" outside of home and work that form "the heart of a community's social vitality," (Oldenburg, 2002; Oldenburg, 1999) and continue expanding the role of public input.

Even without the pandemic, the need for genuinely public spaces pervades many cities in Asia. Observing the situation in Thailand, Malaysia, and other nearby countries, Douglass et al. consider shopping malls in Southeast Asia as "privately owned spaces 
seeking to maximise consumption while limiting all other forms of lifeworld expression" (Douglass et al., 2008; Pomeroy, 20I I). Setha Low has warned about the privatisation of public space in New York and elsewhere, captured by developers and retailers that prey on consumer spending (Low, 2008).

However, alternatives to consumption-based malls have experienced a rise in popularity and may command greater priority in future land-use planning. Hong Kong's malls operated through the pandemic, yet the city has witnessed many more people visiting "country parks" where they can safely distance, rather than typical retail haunts. Their preference for natural landscapes proves the point of Hong Kong's urban researchers and activists (Liber Research), who have consistently resisted proposals to open up cherished nature areas to real estate development (Agence-France Presse, 2018). Cities would do well to ask themselves: do they really need another shopping mall? Or are there public alternatives, such as parks, hiking trails and accessible waterfronts, that would better serve residents in good times and bad?

\section{Cities can accelerate the creation of cycling paths and sidewalks by conceiving of them as alternative public spaces that contribute to resilience, not just enablers of transportation}

The pandemic has clarified the need for expanding public spaces, which are no longer solely about leisure, but also justified in terms of safety and survivability. The recalculation of cost-benefit analyses to include resilience considerations can break the logjam on long-awaited projects such as walking trails, cycling paths, and even sidewalks. In many Southeast Asian cities, sidewalks - taken for granted in the West-do not exist. Pedestrians walk in the road, braving the rush of buses, cars, and motorbikes. While Singapore does have an extensive network of sidewalks, planners often think of them in functional terms-running parallel to stormwater drains, thoroughfares for households to reach bus stops and MRT stations - not as goods in and of themselves.

Yet by widening and upgrading sidewalks, cities can provide more space for human beings to safely enjoy the outdoors. By 2018, the Land Transport Authority had upgraded 200 kilometres of walkways by erecting shelters to protect pedestrians from rain and sun (Land Transport Authority, 2018). Are there further ways to make city pathways pleasurable amenities? Could streets become world-famous destinations, such as the Champs-Elysees in Paris or Las Ramblas in Barcelona?

Incidentally, if sidewalks are reframed as recreational spaces that permit safe yet enjoyable distancing, then keeping them clear and accessible to residents of all ages and physical abilities would become a priority. The popularity of Singapore's Park Connector Network during the pandemic also speaks to the need for accelerating their expansion and ensuring full connectivity, both for enabling non-vehicle mode share, but also as resilient public goods. 


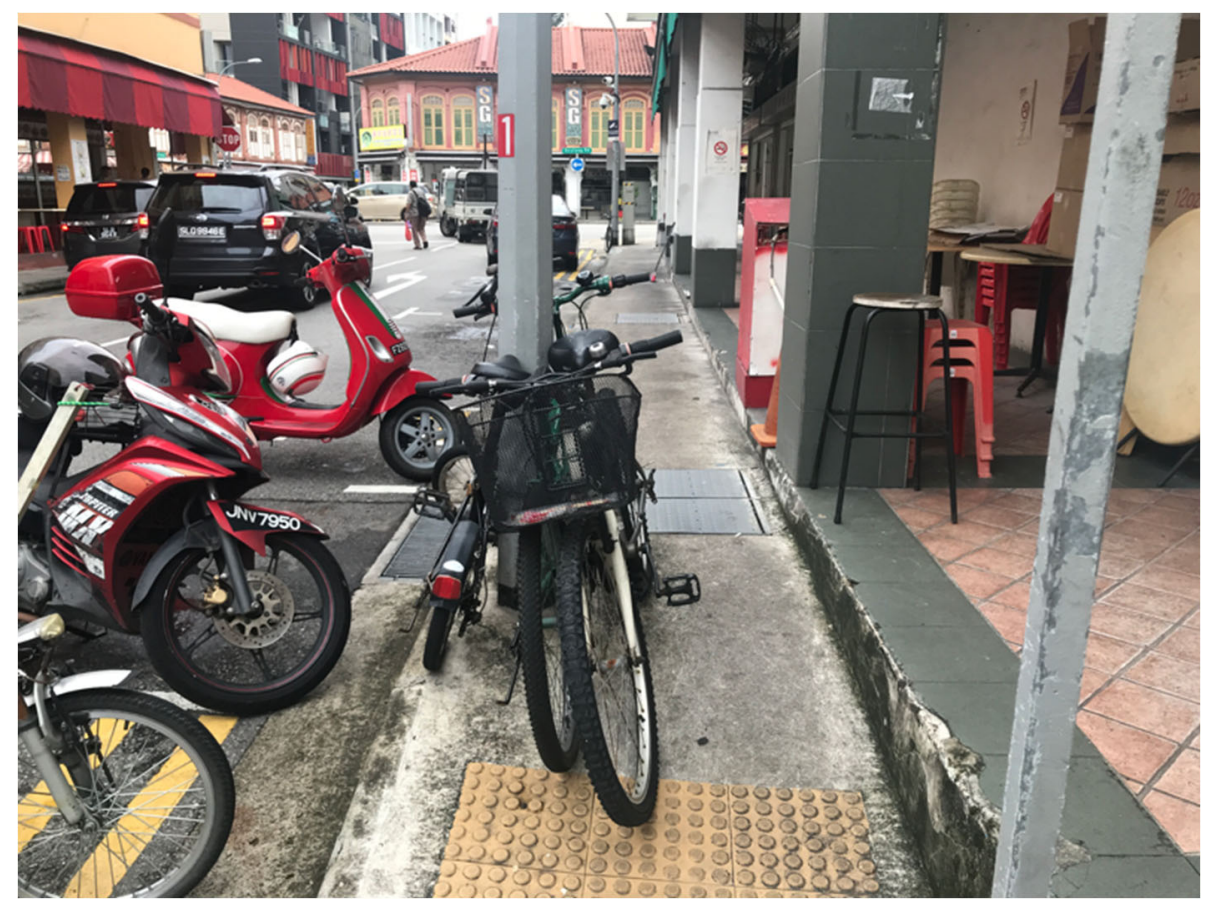

Figure 4. Keeping sidewalks accessible for pedestrians of all physical abilities, including along this lane in Geylang, Singapore, will be increasingly important. Photo by Kevin Hsu.

\section{Spatial equity and socio-economic inequality have come into stark relief, and cities must address these disparities}

A city's neighbourhoods are marked by distinct physical, cultural, and demographic characteristics. Building features that improve quality of life under a pandemic, such as balconies or common walkways, may grace some neighbourhoods but not others. They are also differentiated by residents' ability to access public spaces, whether local, regional or national-level sites. Districts where residents can step outside and easily reach a major park are greatly favoured under a pandemic; places farther from such amenities, and without local substitutes, are at a severe disadvantage.

Studies in the United States have found that access to greenery, community recreation facilities, amenities and programs may differ by income or race (McKenzie et al., 2013; Nexbitt et al., 2019). The availability of ostensibly public resources is unequal, and cannot be taken for granted-a phenomenon even more acutely felt in the current crisis. A possible inspiration lies in historic Savannah, Georgia, which offers the meticulous presence of public squares in each ward, within easy walking distance for residents.

Another dimension requiring scrutiny is the use of "privately-owned, public open spaces" as places for the public to rest and recreate (SPUR, 20I3; Reeves et al., 2020). The concept was popularised in cities such as New York and San Francisco, where developers opened up certain portions of the building in exchange for city incentives. However, some community members have lodged complaints of gate-keeping and intentional inaccessibility of POPOS. 
When the economy shuts in a pandemic, building owners may also choose to close their doors to the public. Rooftop and indoor POPOS could very well be restricted, depriving downtown residents of supposedly public spaces (Hsu, 2018). To resolve this dilemma, cities may need to implement regulatory fixes or engage in negotiations with property managers.

Ultimately, traditional ideas of "accessibility" are due for a rethink, emphasizing quality, not merely presence. There are vast differences among a tiny pocket park, a "privatelyowned, publicly-accessible" open space that can be chained shut by a company, and a large public commons that actually supports physical activity.

To promote spatial equity, and ensure fair and optimal distribution of services and amenities, planners can regularly measure equal/unequal access across the city's neighbourhoods, taking into account demographic factors such as income, race and ethnicity, native language, physical ability, gender and age, to ensure that all populations are appropriately served by the prevailing planning regime-and to identify areas for improvement.

\section{Many urban agglomerations grew out of towns and villages, now amalgamated into metro areas. Older patterns of living, exemplified by historic districts, may enjoy a renaissance}

The pandemic has revealed the disadvantage of residential-only estates, whereas neighbourhoods that contain a full family of amenities-sometimes called "complete communities" or "complete neighbourhoods"- -are getting a second look (City of Portland, 2012; University of Delaware, 2013; Price, 20I8). For example, real estate developers in China regularly build isolated housing projects, which sometimes have a few shops at the margins, but mostly lack the range of services required for everyday life. In contrast, historic neighbourhoods that developed organically over time, such as Laoximen in Shanghai or Dashilar in Beijing, are much likelier to feature a broad set of community-serving establishments.

In Singapore, a number of national-level cultural, entertainment, and leisure destinations are located in or near the downtown core.' Well-loved regional parks are spread out more widely, serving nearby residents, but also attracting users from across the island. Local offerings are diffused across neighbourhoods. Under normal circumstances, residential areas are linked to major attractions by a heavily utilised public transportation system, and the idea of a " 45 -minute city" bound together by trips via bus and rail has been touted as a goal (Singapore Ministry of Transport, 2019) but this concept is challenged during a pandemic, when residents are less willing to take public transit to far-away locations. Options close to home gain added importance (Ministry of Environment and Water Resources, 20I5), yet at present, local amenities do not fully substitute for regional and national-level attractions in terms of quality, level of service, and size.

In a post-COVID world, cities' planning norms are likely to re-prioritise local options, rather than assuming residents will freely travel to national and regional destinations. A

\footnotetext{
I The Singapore Urban Redevelopment Authority's (URA) Digital Planning Lab has developed some useful experimental analyses looking at the availability, accessibility, and diversity of various amenities.
} 
more decentralised model of integrated, full-service neighbourhoods might feature community facilities, a generous selection of dining options, ample offices for workers, places of worship, and greater availability of recreational options and diverse, locallyaccessed public spaces that permit distancing - all to serve distinct human needs. The Mayor of Paris, Anne Hidalgo, has floated the concept of a "fifteen-minute city" where housing, work, provisions, healthcare, education, and leisure should all be accessible to households on foot or by bicycle, without having to use cars or mass transit (Bloomberg, 2020).

One can look to existing developments built by the Housing \& Development Board (HDB) in Singapore as an example, with vibrant town centres and distributed neighbourhood centres offering a wide range of amenities within walking distance of all residents. New residential estates such as Punggol, Bidadari and Tengah are also incorporating neighbourhood centres and expanding parks and cycling paths for residents to enjoy (Housing and Development Board, 2020; Land Transport Authority, 2020). Finally, walkability and distance play some role in the fluid conception of neighbourhood identity and can enhance sense of place (Ewing and Handy, 2009; Zukin, 20 I2; Arup, 2016; Zavattro, 2019). Post-pandemic planning can take advantage of older forms that connect design, amenities, and local identity. Looking ahead, more people may seek out the "kampong" or "village" feel, and pandemic measures that restricted citizens to their neighbourhoods may end up strengthening attachment to place-or increase the desire to live in such places.

\section{Jobs can thrive in decentralised or historic neighbourhoods, but cities and employers must be open to re-imagining workplaces and facilities}

Employment opportunities may migrate outside the Central Business Districttraditionally congested in daytime, but empty at night - shifting the location and physical backdrop of workplaces. Working from home has proven feasible, and is likely to remain popular. Individual entrepreneurs, creative professionals, and employees of small firms looking to stay closer to home can utilize co-working spaces or start-up garages dispersed across a city's neighbourhoods. When remote teams from larger companies choose to gather for collaborative sessions, flexible meeting spaces spread out among regional nodes could be a convenient option. New businesses serving the immediate community could also arise, reducing the need to travel to the city centre and closing the distance between live-work-play.

To accommodate these shifts, planning paradigms would need to evolve, to allow a greater variety of dynamic and mixed land uses. Neighbourhood niches would be filled over time by diverse companies well-suited to that community. Adaptive reuse projects could also end up substituting for premium office space downtown: according to surveys by the National Trust for Historic Preservation in the United States, millennials value social spaces, authenticity, and cultural heritage (National Trust for Historic Preservation, 2017). They would likely appreciate the opportunity to live and work in revitalized, historic neighbourhoods.

Public libraries in Singapore are instructive: today, they function not only as storehouses of reading material, but also as informal workplaces, where freelancers engage in creative projects and conduct business meetings. As the strictures of permanent employment relax due to shifting hiring patterns and generational preferences, freelance 
work is likely to grow (The Straits Times, 2020). Could similar public spaces allow freelance knowledge workers a place to congregate? In the National Library, the existing seating plans already accommodate the I-metre of physical distancing required by the government, allowing them to continue operations in the early phase of COVID-I9. When pondering the future of public spaces, aside from more parks, cities can also consider building covered, air-conditioned spaces with Wi-Fi connectivity and outlets.

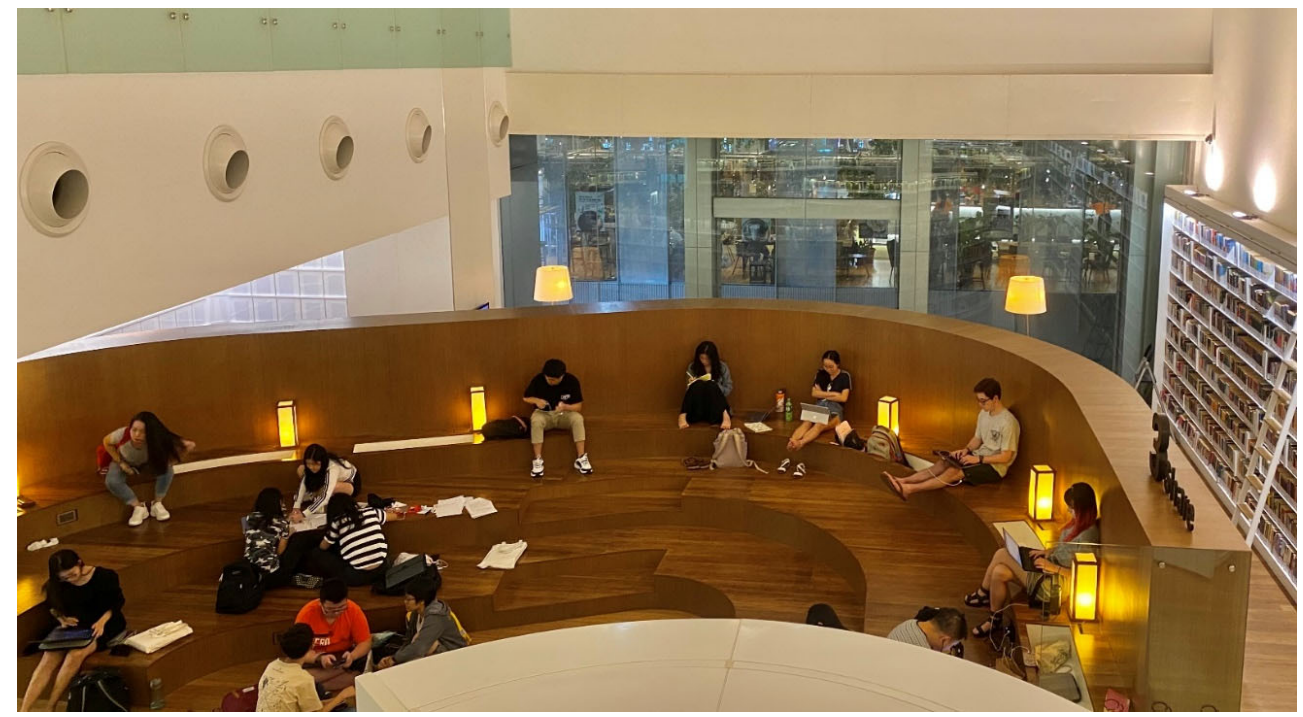

Figure 5. Libraries serve as community gathering places, and even as workplaces for enterprising freelances. Library@Orchard in Singapore. Photo by Kevin Hsu.

The common areas of libraries, museums and other civic buildings could be valued as centres of economic productivity, not written off as crowd-pleasing - but not incomegenerating-social welfare amenities. As an added bonus, people working closer to home could facilitate more frequent interaction among neighbours and strengthen community bonds.

\section{Street closures and placemaking measures that return streets and parking spaces to pedestrians could proliferate after the pandemic}

As of May 2020, more than 50 cities worldwide-including Boston, Cologne,

Philadelphia, London, Vancouver, and Washington D.C.- had closed at least one street or lane to motor vehicles, for some duration of the pandemic, to allow residents more space to exercise at a safe distance from others (Hsu, 2020). Cities have been able to take advantage of the low-traffic period to test out road closures and to complete bike infrastructure, without incurring significant economic impacts.

Even before the pandemic, the Urban Redevelopment Authority of Singapore closed certain streets to vehicle traffic during festivals and celebrations, creating walk-only zones as part of its "place management" strategy. Such place-making approaches could inform immediate and long-term responses to post-pandemic planning, as COVID-19 case counts taper off and cities aim to restore economic vitality by increasing visitor foot traffic. 
Installing more "parklets" to replace roadside parking spaces with public seating-a concept born in San Francisco that mushroomed into a global movement-and converting more roads into outdoor café seating could encourage patrons to return to retail areas (The Guardian, 2016; The Washington Post, 2020). Giving streets back to the people during the pandemic may have initially been motivated by public health, but these efforts may be maintained if they turn out to be economically useful, and sufficiently enjoyable to the public (Hass-Klau, 1993; Lung, 2002).

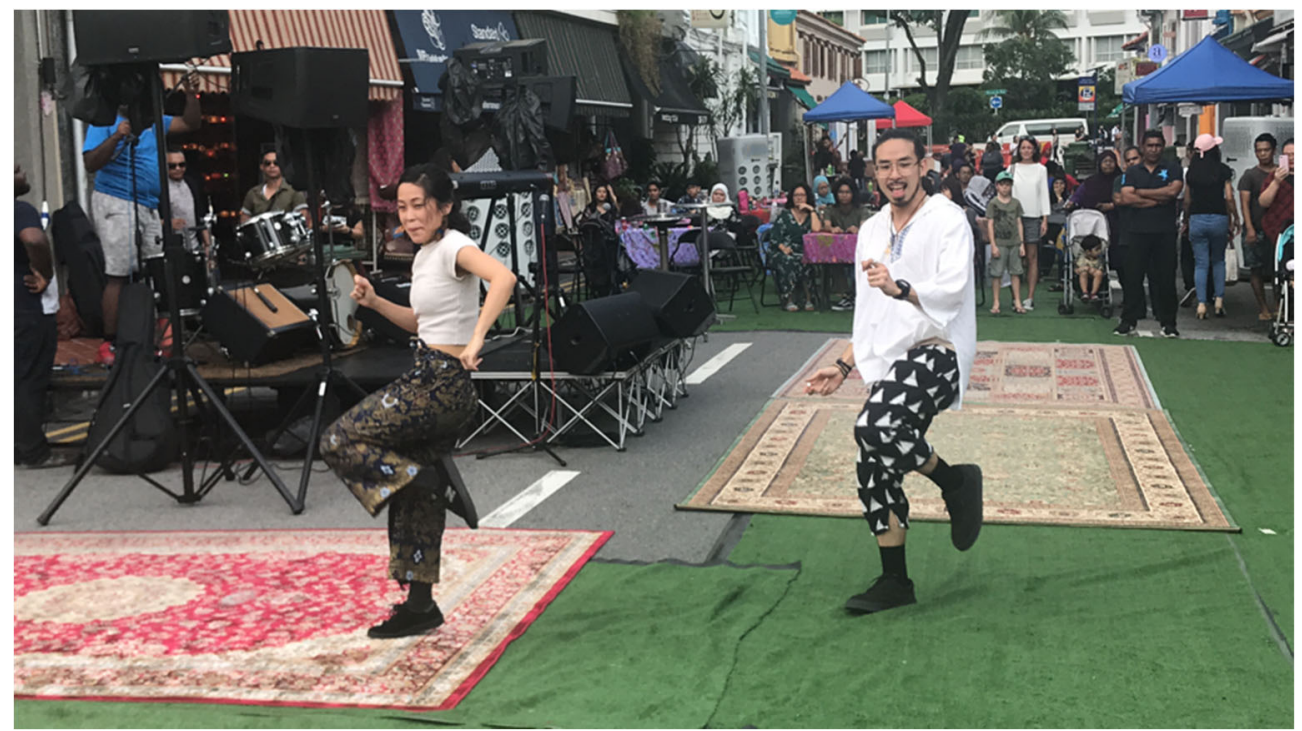

Figure 6. Streets in the Kampong Glam historic district of Singapore were closed to vehicle traffic, and the URA Place Management Department arranged for rugs, seating, live music, and performances during a community event in November 2018. Photo by Kevin Hsu.

\section{Functioning public spaces require empathy, collective responsibility, and mutual respect}

The pandemic renews the debate about what makes for public space. Beyond the provision of physical infrastructure, cities must re-examine the people, activities, and norms that define these spaces. Public perceptions - and citizen behaviour in response to those perceptions - are crucial ingredients that allow spaces to succeed, or to collapse into dysfunction (Center for Active Design, 2018). Ultimately, public space exists where there is public spiritedness. In such places, people feel a sense of welcome; they are able to safely traverse, engage in activities of their choosing, and co-exist alongside others.

Civic pride and empathy for others are key ingredients in a public space ethos. People inculcated with appropriate habits and pro-social mindsets are less likely to litter or vandalise, and to contribute to making spaces safe for all-including minorities and the elderly. Under COVID-19, mask-wearing has emerged as a sign of public spiritedness. In places like Taiwan, Vietnam and Hong Kong, where there has been high compliance with mask-wearing, life remains closer to normal, even with prevention measures. In contrast, intense partisan combat over masks in the United States-interpreted by some groups as an infringement on constitutional rights, but as a reasonable and 
obvious public health policy by most others - has made a return to public activity far more difficult.

Following the pandemic, one hopes members of the public venturing outdoors will feel not only great relief from confinement, but also a resurgent sense of ownership and pride over public spaces. Ideally, they would cherish these spaces, seeing the commons as a place all citizens have the responsibility to maintain —and the opportunity to curate.

\section{Ensuring public spaces for all}

As cities emerge from the pandemic, the lessons learned about our public spaces can positively influence the future management and planning of cities. Cities must now consider public spaces a critical element of resilience, not only recreational amenities. These public spaces must accommodate more diverse (and distanced) activities, and be prepared to alter their function in public health emergencies.

Informal public spaces, sidewalks, and cycling paths are excellent public goods that cities can quickly expand. With some imagination, these can transcend mere mobility to enhance quality of life and survivability. However, all of these amenities must be viewed through a lens of social and spatial equity: not every resident has easy access to the same public goods. A more nuanced stock-taking of the range, quality, and availability of public spaces will help in this effort.

Fortunately, traditional neighbourhoods that developed organically over time offer design inspirations to promote equitable access and daily convenience, and can accommodate the dispersal of jobs. The possible rise of decentralised, "complete" neighbourhoods may turn out to be a boon for local public spaces, with civic buildings re-imagined as nodes of collaboration and knowledge-based economic activity. In taking a reference from placemaking, cities that prioritise streets for pedestrians and cyclists can help attract foot traffic and restore economic vitality, though these measures must be balanced with public health concerns over crowding. Ultimately, maintaining lively and welcoming public spaces requires empathy, respect for the commons, and care for others, manifested in health-promoting behaviours such as wearing masks.

Physical spaces in a city can only be fully and genuinely "public" if they are open to allregardless of age, language, sexual orientation, cultural identity, or ability. Achieving this aspiration post-pandemic requires making spaces safe, secure, and broadly accessible. At the same time, cities will lift restrictions and restore creative freedoms to rejuvenate public places. Striking the right balance between these priorities requires citizens and government to partner for the common good.

Under normal conditions, city residents and planners may overlook and undervalue public spaces. The global pandemic has given humanity a long moment of pause, reminding governments and publics of the fundamental need for social connection and association. Humans need civic places where we co-exist with others, and where we feel a sense of connection to the larger community. In the process of rebuilding and recovery, cities must strive to ensure such places are available to all.

\section{Acknowledgment}

The author wishes to thank Michael Koh for his encouragement and feedback on this article. 


\section{References}

Agence France-Presse (2018) 'Wild Hong Kong: Fans of Country Parks Oppose Concreting of Trails, Taking Land for Homes', South China Morning Post, 6 January [online]. Available at: https://www.scmp.com/lifestyle/travel-leisure/article/2 I 270 I8/wild-hong-kong-fans-countryparks-oppose-concreting-trails (Accessed May 2020).

Arup (2016) Cities Alive: Toward a Walking World [online]. London: Arup. Available at: https://www.arup.com/perspectives/publications/research/section/cities-alive-towards-awalking-world (Accessed June 2020).

Bassett, E. M. (1938). 'The Master Plan' in LeGates, R and Stout, F. (1998) (eds.) Early Urban Planning: 1870-1940. New York: Routledge.

Beatley, T. (2017) Handbook of Biophilic City Planning \& Design. Washington, DC: Island Press.

Butler, S. and Diaz, C. (2016) "Third Places" as Community Builders [online]. Available at: https://www.brookings.edu/blog/up-front/2016/09/14/third-places-as-community-builders (Accessed: May 2020).

Center for Active Design (20I8). The Assembly Civic Engagement Survey [online]. Available at: https://centerforactivedesign.org/assembly-civic-engagement-survey (Accessed June 2020).

Centre for Liveable Cities and National Parks Board, Singapore. (2015) Biodiversity: Nature Conservation in the Greening of Singapore [online]. Available at: https://www.clc.gov.sg/docs/default-source/urban-systems-studies/uss-biodiversity.pdf (Accessed: May 2020).

City of Portland. (2012) The Portland Plan [online]. Portland: City of Portland. Available at: https://www.portlandonline.com/portlandplan/index.cfm?c=58776 (Accessed May 2020).

Design Council UK. (2003). The Value of Public Space: How High Quality Parks and Public Spaces Create Economic, Social and Environmental Value [online]. London: Bartlett School of Planning. Available from: CABE Space (Accessed May 2020).

Douglass, M., et al. (2008) 'The Livability of Mega-Urban Regions in Southeast Asia' in Jones, G. and Douglass, M (eds.) Mega-Urban Regions in Pacific Asia: Urban Dynamics in a Global Era. Singapore: NUS Press, pp. 284-319.

Er, K. (20I8) Growing a Biophilic City in a Garden [online]. Available at: https://www.csc.gov.sg/articles/growing-a-biophilic-city-in-a-garden\#notes (Accessed: May 2020).

Ewing, R and Handy S. (2009) 'Measuring the Unmeasurable: Urban Design Qualities Related to Walkability', Journal of Urban Design, I4(I), Pp. 65-84.

Goto, S. (2003) The Japanese Garden: Gateway to the Human Spirit. New York: P. Lang.

Gul, M., Dee, J., and Ozdemir, C. (2014) 'Istanbul's Taksim Square and Gezi Park: the Place of Protest and the Ideology of Place', Journal of Architecture and Urbanism, 38(I), pp. 63-72.

Hammitt, W.E. (2002) 'Urban Forests and Parks as Privacy Refuges', Journal of Arboriculture, 28(I), PP. $19-26$.

Hammond, T. (2019) 'The Politics of Perspective: Subjects, Exhibits, and Spectacle in Taksim Square, Istanbul', Urban Geography, 40(7), pp. 1039-54.

Harnik, P. (20I2) Urban Green: Innovative Parks for Resurgent Cities. Washington, DC: Island Press.

Hass-Klau, C. (1993) 'Impact of Pedestrianization and Traffic Calming on Retailing A Review of the Evidence from Germany and the UK', Transport Policy, I (I), PP. 2I-3I.

Heat, H.S. (2019) DPM Heng Swee Keat at the "Building Our Future Singapore Together" Dialogue. Prime Minister's Office, Singapore [online]. Available at: https://www.pmo.gov.sg/Newsroom/DPM-Heng-Swee-Keat-Building-Our-Future-SingaporeTogether-Dialogue (Accessed May 2020).

Hee, L. and Ooi, G.L. (2003) 'The Politics of Public Space Planning in Singapore', Planning Perspectives, I8(I), PP. 79-103.

Hee, L. (2017) Constructing Singapore Public Space. Singapore: Springer.

Henderson, J. (2012) 'Urban parks and green spaces in Singapore', Managing Leisure, I8(3), Pp. $213-23$. 
Housing and Development Board, Singapore. (2020) Neighbourhood Centres [online]. Available at: https://www.hdb.gov.sg/residential/living-in-an-hdb-flat/my-neighbourhood/neighbourhoodcentres (Accessed June 2020).

Hsu, K. F. (2018) Urban Gems of San Francisco: Privately-owned Public Open Spaces (POPOS) [online]. Available at: https://www.youtube.com/watch? $v=J M U 2 w c N h S f Q$ (Accessed May 2020).

Hsu, K. F. (2020) 'Uniting Health, Mobility and Urban Resilience: Verified City Actions to Create Public Space for Walking and Biking During the Pandemic', Working Paper.

Johnson, N. (2002) 'Mapping Monuments: The Shaping of Public Space and Cultural Identities', Visual Communication, I (3) [online]. Available at: https://doi.org/I0.I I 77//477035720200I00302 (Accessed: May 2020).

Kang, J.C. (2020) 'Inequality Has Been Laid Bare by the Outbreak. Now What?' The New York Times, 20 May, Available at: https://www.nytimes.com/interactive/2020/05/20/magazine/covidquarantine-inequality.html (Accessed May 2020).

Khoo, T.C. (2017) Singapore: The First City in Nature? [online]. Available at: https://www.clc.gov.sg/research-publications/publications/digital-library/view/singapore-thefirst-city-in-nature (Accessed: May 2020).

Kwok C. and Chan N.K. (2020) 'The Making of Contentious Political Space: The Transformation of Hong Kong's Victoria Park', Space and Culture [online]. Available at: I0.1 177//20633 I2209/2160 (Accessed: May 2020).

Land Transport Authority, Singapore. (2020) Factsheet: Islandwide Cycling Network (ICN) Programme to Improve Safety and Connectivity for all Path Users [online]. Available at: https://www.lta.gov.sg/content//tagov/en/newsroom/2020/3/news-releases/islandwide-cyclingnetwork--icn--programme-to-improve-safety-and.html (Accessed June 2020).

Land Transport Authority, Singapore. (2018) 'LTA Completes $200 \mathrm{~km}$ of Sheltered Walkways Under Walk2Ride Programme', 2 September [online]. Available at: https://www.lta.gov.sg/content/ltagov/en/newsroom/2018/9/2/factsheet-lta-completes-200kmof-sheltered-walkways-under-walk2ride-programme.html (Accessed May 2020).

Laris, Michael. (2020) 'Cities are Closing Streets to Make Way for Restaurants and Pedestrians', The Washington Post, 25 May [online]. Available at: https://www.washingtonpost.com/local/trafficandcommuting/cities-are-closing-streets-tomake-way-for-restaurants-and-pedestrians/2020/05/25/Iflaf634-9b73-I l ea-ad098da7ec214672_story.html (Accessed May 2020).

Larson et. al. (2016) 'Public Parks and Wellbeing in Urban Areas of the United States', PLOS One, I I (4) [online]. Available at: https://doi.org/I0.137//journal.pone.01532II (Accessed: May 2020).

Lee, K.Y. (2000) From Third World to First: The Singapore Story-1965-2000. Singapore: Times Editions.

Lee, N. (2009) 'How is a political public space made? - The birth of Tiananmen Square and the May Fourth Movement', Political Geography, 28(I), Pp. 32-43.

Lennon, M., Douglas, and O., Scott, M. (2017) 'Urban Green Space for Health and Well-Being: Developing an 'Affordances' Framework for Planning and Design', Journal of Urban Design, 22(I) [online]. Available at: 10.1080/I3574809.2017. I336058 (Accessed: May 2020).

Liber Research. (2018) Genuine Options for Future Land Development: Research and Public Consultation 未來土地發展真實選項：好誠實研究及公眾諮詢 [online]. Available at: https://liberresearch.com/research-category/land-supply/ (Accessed: May 2020).

Low, S. (2008) 'The Erosion of Public Space and the Public Realm: Paranoia, Surveillance and Privatization in New York City', City \& Society, I8(I), pp. 43-9.

Low, S., Taplin, D. and Scheld, S. (2005) Rethinking Urban Parks: Public Space and Cultural Diversity. Austin: University of Texas Press.

Lund, H. (2002) 'Pedestrian Environments and Sense of Community', Journal of Planning Education and Research, $2 \mathrm{I}(3)$, PP. 30I-I2. 
Lutzoni, L. (2016) 'In-Formalised Urban Space Design: Rethinking the Relationship Between Formal and Informal', City Territ Archit, 3(20) [online]. Available at: https://doi.org/I0.1 186/s40410-016-0046-9 (Accessed: May 2020).

Maas J. et al. (2009) 'Morbidity Is Related to a Green Living Environment', Journal of Epidemiology \& Community Health, 63 (I2) [online]. Available at: 10.I I36/jech.2008.079038 (Accessed: May 2020).

Mason, R. (2006) 'Theoretical and Practical Arguments for Values-Centered Preservation', CRM: The Journal of Heritage Stewardship, 3(2), pp. 21-49.

McKenzie, T.L., et al. (2013) 'Neighbourhood Income Matters: Disparities in Community Recreation Facilities, Amenities, and Programs', Journal of Park and Recreation Administration, 3I (4), pp. I2-22.

Ministry of Environment and Water Resources. (2015) Our Home, Our Environment, Our Future. Sustainable Singapore Blueprint [online]. Singapore: Ministry of Environment and Water Resources. Available from: https://smartnet.niua.org/sites/default/files/resources/Sustainable\%20Singapore\%20Blueprint\% 2020I5.pdf (Accessed May 2020).

Ministry of Transport, Singapore. (2019) Government accepts Land Transport Master Plan 2040 Advisory Panel's Recommendations [online]. Government of Singapore. Available at: https://www.mot.gov.sg/news-centre/news/detail/government-accepts-land-transport-masterplan-2040-advisory-panel-s-recommendations (Accessed May 2020).

National Library Board, Singapore (2020) "Garden City" vision is introduced I I th May 1967 [online]. Available at: http://eresources.nlb.gov.sg/history/events/a7fac49f-9c96-4030-8709cel60c58d I5c (Accessed: May 2020).

National Parks Board, Singapore. (2020) City in Nature [online]. Available at: https://www.nparks.gov.sg/about-us/city-in-nature (Accessed: May 2020).

National Trust for Historic Preservation, United States and Edge Research. (2017) Millennials and Historic Preservation: A Deep Dive Into Attitudes and Values Results from an Online Survey of Millennials [online]. Washington, DC: National Trust. Available at: https://nthpsavingplaces.s3.amazonaws.com/2017/06/27/09/02/25/407/Millennial\%20Research\%20Report.p df (Accessed June 2020).

Nexbitt, L., et al. (2019) 'Who Has Access to Urban Vegetation? A Spatial Analysis of Distributional Green Equity in 10 US Cities', Landscape and Urban Planning, I8I (Jan), Pp. 5I79.

Oldenburg, R. (1999) The Great Good Place: Cafes, Coffee Shops, Bookstores, Bars, Hair Salons, and Other Hangouts at the Heart of a Community. Lebanon: De Capo Press.

Oldenburg, R. (2002) Celebrating the Third Place. Lebanon: De Capo Press. O'Sullivan, F. (2020). 'Paris Mayor Pledges a Greener 15 Minute City', Bloomberg, 18 February [online]. Available at: https://www.bloomberg.com/news/articles/2020-02-I8/paris-mayorpledges-a-greener-I 5-minute-city (Accessed May 2020).

Parkinson, J. (20I2) Democracy and Public Space: The Physical Sites of Democratic Performance. Oxford: Oxford University Press.

Peiser, R. and Schwann, G. (1993) 'The Private Value of Public Open Space Within Subdivisions', Journal of Architectural and Planning Research, I0(2), Pp. 9I- 104.

Peters, K., Elands, B., and Buijis, A. (20I0) 'Social Interactions in Urban Parks: Stimulating Social Cohesion?', Urban Forestry \& Urban Greening, 9(2), pp. 93-100.

Pilkington, E. (2020) 'Black Americans dying of Covid-19 at three times the rate of white people,' The Guardian, 20 May. Available at: https://www.theguardian.com/world/2020/may/20/blackamericans-death-rate-covid-19-coronavirus (Accessed: May 2020).

Pomeroy, J. (20II) 'Defining Singapore Public Space: From Sanitization to Corporatization', Journal of Urban Design, 16 (3), pp. 38I-396. 
Price, A (2018). We Need Complete Neighborhoods [online]. Strong Towns. Available at: https://www.strongtowns.org/journal/2018/2/6/complete-neighborhoods (Accessed June 2020).

Project for Public Spaces (2009) 10 Benefits of Creating Good Public Spaces [online]. Available at: https://www.pps.org/article/l Obenefits (Accessed: May 2020)

Reeves, B., et al. (2020) The Best Privately-Owned Public Open Spaces in SF [online]. Curbed San Francisco. Available at: https://sf.curbed.com/maps/sf-parks-private-popos-public-ownedspaces-downtown (Accessed May 2020).

Rowe, P. and Hee, L. (2019) A City in Blue and Green: The Singapore Story. Singapore: Springer.

Rupprecht, C.D.D. and Byrne, J.A. (20I4) 'Informal Urban Greenspace: A Typology and Trilingual Systematic Review of Its Role for Urban Residents and Trends in the Literature', Urban Forestry \& Urban Greening, I3(4), pp. 597-6 I I.

Seow, J. (2020) 'More Singapore Residents Working as Freelancers', The Straits Times, 3I January [online]. Available at: https://www.straitstimes.com/singapore/manpower/more-residentsworking-as-freelancers (Accessed May 2020).

SPUR. (2013) A Guide to San Francisco's Privately-Owned Public Open Spaces: Secrets of San Francisco [online]. San Francisco: SPUR. Available at:

https://www.spur.org/sites/default/files/migrated/anchors/popos-guide.pdf (Accessed May 2020).

Sturm, R. and Cohen, D. (20I4) 'Proximity to Urban Parks and Mental Health', J Ment Health Policy Econ, I7(I), pp. 19-24.

Taylor, D. E. (2009) The Environment and the People in American Cities, 1600s-1900s: Disorder, Inequality, and Social Change. Durham: Duke University Press.

Teo, P. (1997) 'Space to Grow Old In: The Availability of Public Spaces for Elderly Persons in Singapore', Urban Studies, 34(3), pp. 419-39.

Teo, G. (2019) "'45-minute city, 20-minute towns": Advisory panel outlines vision for Land Transport Master Plan 2040', Channel News Asia, 12 January [online]. Available at: https://www.channelnewsasia.com/news/singapore/45-minute-city-20-minute-towns-landtransport-master-plan-2040-I I I I 4494 (Accessed May 2020).

Thorpe, A. (2016) 'A Day for Turning Parking Spaces Into Pop-up Parks', The Guardian, I5 September [online]. Available at: https://www.theguardian.com/artanddesign/2016/sep/15/aday-for-turning-parking-spaces-into-pop-up-parks (Accessed May 2020).

Thralls, C. (2018) 'Urban Parks as Sacred Places: Pilgrimage, Solitude, and Access to Nature', Studies in Spirituality, 28, pp. 21 I-3I.

UNESCO. (2015) Singapore Botanic Gardens [online]. Available at: https://whc.unesco.org/en/list/l 483 (Accessed: May 2020).

University of Delaware. (2013) Complete Communities Toolbox [online]. Available at: https://www.completecommunitiesde.org (Accessed June 2020).

Valentino-DeVries, J., Lu, D., Dance, G.J.X. (2020) 'Location Data Says It All: Staying at Home During Coronavirus Is a Luxury,' The New York Times, 3 April, Available at: https://www.nytimes.com/interactive/2020/04/03/us/coronavirus-stay-home-rich-poor.html (Accessed May 2020).

Whyte, W.H. (1980) The Social Life of Small Urban Spaces. 200 I reprint. New York: Project for Public Spaces.

Yan, G. (2020) 'Public Engagement for Pasir Panjang Park Kicks Off Park Co-creation Programme', 18 January [online]. Available at: https://www.straitstimes.com/singapore/environment/publicengagement-for-pasir-panjang-park-kicks-off-park-co-creation-programme (Accessed: May 2020).

Zavattaro, S. (2019) Place Brand Formation and Local Identities. London: Routledge.

Zukin, S. (2012) 'The Social Production of Urban Cultural Heritage: Identity and Ecosystem on an Amsterdam Shopping Street', City, Culture and Society, 3(4), pp. 28I-29I. 